\title{
If You've Ever Gone Out With One Then You'll Know What I Mean
}

\author{
Heather Simeney MacLeod
}

\begin{abstract}
J'étais assise dans Paradise Park (plus tard, j'ai découvert qu'il s'appelle en réalité Riverside Park, mais il garde pour moi le nom de Paradise Park) par un soir pluvieux d'automne, un peu triste sans doute, un carnet sur les genoux, pensant aux lignes (qui sont devenues le titre du poème) d'une auvre de Rebecca Fredrickson. Je me souviens très clairement m'être lamentée sur la disparition de Pearl Jam, de Nirvana, des jeans déchirés, des caleçons longs, des dessous en flanelle, d'Edie Brickell, des soirées détrempées de mes premières années d'université à Victoria.
\end{abstract}

All love is punk love.It's punk in the bone when you're hung-over or tweaking and wondering if he'll ever call again, or even try to bump into you while you're squeezing tomatoes and wearing those striped, jock pants, which show, painfully show, your saddlebags, and you wonder, while a young man is standing stiffly in his faded denim with his patches kind of curling at the ends, whatever happened to your youth anyway. Like, when did that slip away? And, you kind of try to straighten your hair, which has too much curl in it today, and there is a wayward strand refusing to be constrained, and it's hanging in a long, wild curl down the centre of your face, and the young man is sipping an Americano and asking you some inane question, and you realize he's like at least ten years younger than you, but he smells so good, and he's so busy being intelligent and profound that you feel amused, and he's flicking a thick joint back behind his ear and, so, you follow him out to his car where he plays his music too loud and drives you home, shifting gears too soon, kind of jack-rabbiting at the intersection before Lolo Street, and he follows you into your bedroom and loves you up like you're worthwhile, like you're still 23, like you're everything that he has ever wanted. 